\title{
'The Lemonade Stand Project:' A Refreshing Approach to Teaching Undergrads
}

\author{
Jay Ebben (University of St. Thomas) \\ Alec Johnson (University of Saint Thomas)
}

KEYWORDS: Entrepreneurship, Teaching Methods, student entrepreneurs, mentors.

The very first course in most undergraduate entrepreneurship concentration sequences has traditionally been a survey course, designed to give students a theoretical framework and practical understanding of a career in entrepreneurship and business development. To be blunt, these courses are generally pretty stale -- neither active, experiential nor engaging -- and they don't accomplish the goals we've set for our students.

We had a vision for redesigning this course to better reflect our belief that no one is too young to create significant value. To impress this belief upon students, we set out to establish three core elements: 1) The confidence that they can start a business, 2) A connection between entrepreneurship and the larger picture, and 3) A community of resources and support.

We felt that we could accomplish this by moving toward an experiential-based pedagogy, while retaining an important balance with theory. Starting with the spring semester of 2012, we organized the course around students launching a business. While this approach is not new, how we implemented this and other features is what made the course innovative and valuable.

The redesigned course focuses on opportunity assessment, unique value proposition, business models, organizational strategy and growth, and some introductory financial concepts. The core of the redesigned course is called the Lemonade Stand Project.

\section{The Lemonade Stand Project}

The central feature of the course was the assignment to launch a business. Students were given two goals and one constraint for this assignment. The goals were to build a brand that could earn revenue by the end of the semester and continue beyond it. The constraint was that all businesses launched would be loosely related to a lemonade stand. We introduced a constraint because our experience has led us to conclude that student creativity is inhibited when facing a blank white board with no constraints. We believed that a single, rather loose constraint would provide a springboard to launch the students' creativity and engage their entrepreneurial spirit. Students were free to start any business that captured the spirit of the culturally ubiquitous lemonade stand and were granted a great deal of latitude on the approach to this concept. Teams were then organized, and the teams were told to develop a concept and prepare to present the concept early in the semester. The following actual team projects help illustrate the creative approaches we were seeking:

- Selling winter hats branded "Love Your Melon," with the concept of giving a hat to a child with cancer for every hat sold (this team sold $\$ 4500$ of hats in four days and has been featured on two of the Minneapolis new stations);

- Creating an online campus newspaper called "The Lemon" to highlight overlooked or controversial campus news using sarcasm (this team is still in business and now has more than 250 Facebook followers);

- Designing and building a wagon add-on kit for a lemonade stand (this product was picked up by a local toy store at the end of the semester and they sold eight units at $\$ 150$ each);

- Creating a fund to invest in Kiva entrepreneurs by selling self-designed "Lemonaid" t-shirts (this team sold over $\$ 1000$ of t-shirts and lemonade and invested in five entrepreneurs by semester end). 


\section{The 'Hotwash'}

A critical feature of the course was the "hotwash" process. This is a peer mentoring process in which students provide their insights, ideas and feedback to one another. Peer monitoring, not from instructors or external entrepreneurs, is crucial to the success of the exercise. The instructor's job is to maintain a positive atmosphere; encourage questions, comments and ideas from the audience; and to avoid, as much as possible, telling the students "how to do it." The unique value of the hotwash comes from the lack of power differential between the presenters and those providing feedback. It empowers students to push back on ideas, challenge one another and defend their concepts. Instructors and traditional mentors come to these discussions in a powerful position and generally with an air of "we know best." This power differential stifles creativity, lessens student engagement and critically, lowers students' sense of ownership at this early stage of development. The hotwash is the starting point for building confidence, connection and community.

During the first three weeks of the semester, students were asked to hotwash their concepts before the class. Students then hotwashed their concepts again several weeks later. Many also chose to hotwash them at our informal student organization, Practicing Entrepreneurs, during the semester.

The hotwash begins with each team pitching their idea in 10 minutes or less to the other students. They then answer questions from their peers regarding target markets, product design, business model, market positioning and execution, and gather suggestions on how to improve their concept, approach to the market, etc. A hotwash generally lasts about 30 minutes. As an Instructor, it is critical to maintain a positive constructive atmosphere, but also to encourage the free exchange of ideas. You may need to spur discussion with well-timed questions, such as "Can you describe your target customer?" or "Can you explain the problem you're trying to solve in more detail and who you're solving it for?" In our experience, after a few hotwashes the instructor can stand back and simply manage the traffic. There were several predictable and valuable outcomes to our hotwash process:

- All students could bear witness to the variety of creative ways to approach a "Lemonade Stand" business;

- Students were exposed to challenges and weaknesses in their plan and had an opportunity to pivot;

- Students began learning how to make a business case and build their confidence to present it to an audience.

- The class rapidly becomes a community of entrepreneurs helping and supporting one another in their efforts to create a venture.

\section{Mentorship, Web Design and the Competition}

In addition to the focus on a lemonade stand and the hotwash process, three other elements made this project unique:

Mentorship: We put a unique twist on the concept of mentorship by requiring the seniors in our capstone course to serve as mentors to sophomore teams in the introductory course. This twist created across-course integration for the first time in our program. Teams and mentors were required to meet a minimum of four times, but the introductory students were responsible for scheduling meetings and developing agendas. In the very first engagement with mentors, introductory teams were required to make an investor pitch. Using seniors as mentors tempered the power differential between mentor and mentee and also provided a valuable learning experience for our seniors. As the old saying goes "if you really want to learn something, teach it."

Web Development: To address a weakness in our students' background, they were required to build a web site and Facebook page in support of their lemonade stand business. To facilitate this, all students attended a seminar on building Wordpress web sites given by a successful technology alum. A number of teams went so far as to build e-commerce into their sites, such as the Love Your Melon team (www.loveyourmelon.com (http://www.loveyourmelon.com) ).

-

End-of-Semester Competition: Each team was required to submit a written report and also 
present to a panel of alumni judges at the end of the semester, in which they discussed their concept, goals, execution, results and lessons learned. The judges selected the top three teams, who were then eligible for internships.

\section{Course Outcomes}

Our experiment in redesigning the introductory undergraduate entrepreneurship course has been a success. The Lemonade Stand project is a truly unique experiential project, highlighting the importance of creativity and execution in entrepreneurship. The alumni judges at the final competitions were very impressed, and told us over and over, "We couldn't have done that when we were in this class!" They were right to be impressed; we asked a great deal from sophomores in their first entrepreneurship course, and several teams more than exceeded our expectations. Furthermore, the level of execution continues to improve over time.

What we heard from students validates that our approach is effectively conveying messages around confidence, connection and community. In the "Lessons Learned" section of the final paper, students talked about realizing that they can start a business; the importance of being able to communicate their value proposition succinctly; the need to be persistent and open to adjusting business models; the significance of a support network; the concept that a business is about far more than just making money; and many other valuable lessons.

Two other outcomes were significant. First and foremost, the level of enthusiasm and maturity from students is already higher. We saw several variations of the following two quotes in course evaluations: "I can honestly say that I will be walking away from this course with a new passion in life," and "This class has been one of the most influential of my college career." Students are developing an expanded vocabulary and understanding of core issues. Additionally, they also have a deeper engagement with other entrepreneurship students, and everyone in our program is now interested in the "lemonade stands" that are being developed in our introductory course.

Second, the level of enthusiasm for what we are doing is higher all over campus. Several articles have been written in the campus newspaper on the "Lemonade
Stand" course, and as a result we have attracted students from other disciplines to our classes and extracurricular programs.

In conclusion, we have significantly innovated experiential learning in our introductory course to convey messages around confidence, connection and community. Our model is especially valuable because it is easily replicable: it is a single-semester course and we do not provide funding to students.

\section{More ideas}

College business professors looking for more ideas to enrich the classroom experience can find them here (https://eiexchange.com/eix-in-class) .

Additional Search Terms: successful companies led by students, entrepreneurial thinking, entrepreneurship courses, Love Your Melon, mentorship 